\title{
Response of Pigeon Pea to Drip Irrigation and Mulching
}

\author{
M.A. Solanki*, A.L. Chalodia, M.H. Fadadu and P.V. Dabhi \\ Department of Soil and Water Engineering, College of Agricultural Engineering and \\ Technology, Navsari Agricultural University, Dediapada - 393040, Gujarat, India
}

*Corresponding author

\begin{tabular}{|l|}
\hline Ke y w o r d s \\
$\begin{array}{l}\text { Drip irrigation, } \\
\text { Yield, Water use } \\
\text { efficiency and } \\
\text { Economics }\end{array}$ \\
\hline Article Info \\
\hline $\begin{array}{l}\text { Accepted: } \\
\text { 04 January } 2018 \\
\text { Available Online: } \\
\text { 10 February } 2019\end{array}$ \\
\hline
\end{tabular}

\section{Introduction}

In traditional day of agriculture, legumes are essential components because of their ability to enrich soil nitrogen status, effectiveness in improving soil structure, qualitative increase in micro-organism population. The Pigeon pea [Cajanus cajan (L.) Millsp.] is known by numerous names with different etymologies,

\section{A B S T R A C T}

The investigation entitled "Response of pigeonpea to drip irrigation and mulching" conducted at college farm, CAET, NAU, Dediapada, during rabi season 2017-18. The experiment consisted of five irrigation treatments and laid-out with randomized block design taking four replications. There were three treatments based on surface drip irrigation method and irrigation schedules in the form of pan evaporation replenishment factors of 0.6 and were either kept constant throughout the crop life and two treatments consisted of irrigation through a furrow system of irrigation scheduled at an IW/CPE: 1 with an irrigation water depth of $60 \mathrm{~mm}$ was maintained. Growing of rabi pigeonpea resulted significantly higher yield due to 0.6 significantly higher in $0.6 \mathrm{PEF}$ through drip irrigation with sugarcane trash mulch @ 5 t/ha. Yield attributes as well as yields of pigeonpea were also produced higher through drip with sugarcane trash mulch @ $5 \mathrm{t} / \mathrm{ha}$. The interaction effect observed between irrigation and mulch were significant in respect to plant height at harvest $(182.66 \mathrm{~cm})$, number of secondary branches $(23.04)$, grain yield (3318.4 kg/ha), haulm yield $(2615.24 \mathrm{~kg} / \mathrm{ha})$, fodder yield $(2712.21 \mathrm{~kg} / \mathrm{ha})$, stalk yield $(7749.17 \mathrm{~kg} / \mathrm{ha})$, dry root weight $(1590.28 \mathrm{~kg} / \mathrm{ha})$, harvest index $(24.26 \%)$ and water use efficiency $(6.84 \mathrm{~kg} / \mathrm{ha}-\mathrm{mm})$ as compared to rest treatment. WUE decreased with increase in level of irrigation. Drip irrigation 0.6 PEF with sugarcane trash mulch @ $5 \mathrm{t} / \mathrm{ha}$ recorded higher WUE with 34.79 per cent water saving as compared to surface irrigation (control). The interaction effect of drip irrigation $0.6 \mathrm{PEF}+$ sugarcane trash mulch @ $5 \mathrm{t} / \mathrm{ha}$, 56 per cent coverage recorded higher net returns (136475.99 Rs/ha) and benefit cost ratio (3.66). For getting potential production and profit from the rabi pigeonpea, scheduling of irrigation at $0.6 \mathrm{PEF}$ through drip with sugarcane trash mulch @ $5 \mathrm{t} / \mathrm{ha}$.

"tropical green pea", gungo pea in Jamaica, 'tuver' 'tour' or 'arhar' in India, 'redgram' and gandule bean is a perennial legume from the family Fabaceae, and one of the major legume crops of the tropics and subtropics (Vanaja et al., 2010). Compared with other legumes, pigeon pea ranks only the sixth in area and production in the world, but it is used in more diverse ways than others $(\mathrm{Wu}$ et 
al., 2009 and Domoguen et al., 2010). Pigeon pea has been considered as second most important crop after chickpea (Cicer arietinum). India has virtual monopoly in pigeon pea production accounting to $90 \%$ of world's total production. In India, pigeonpea is grown in an area of $4.37 \mathrm{M} \mathrm{Ha}$, with a production of $2.65 \mathrm{MT}$ and the average productivity is $655 \mathrm{~kg} / \mathrm{ha}$. More than $85 \%$ area of pigeon pea is under rain fed. In Gujarat, 0.29 million tones pigeon pea produced from 0.26 million ha area along with productivity of $1109 \mathrm{~kg} / \mathrm{ha}$ (Anonymous, 2010). Pigeon pea is generally grown under rain fed condition (June-November). It is grown as a rabi crop in the south where mild winter prevails, in which case the sowing is done in September-October, and harvesting in March-April.

The crop benefits from irrigation if dry spells prevail for long periods, low relative humidity, mild temperature and low incidence of pest and diseases. Besides, the crop has to face less competition from weeds and responds better to apply inputs. Flower initiation (about 75 days after sowing) and pod filling (about 100 days after sowing) are found to be more responsive to irrigation for short duration pigeon pea. The demand for pulses is increasing due to increasing population. Indian Council of Medical Research recommends about $60 \mathrm{~g} /$ day/person, but the average intake is only $31 \mathrm{~g} /$ day (NNMB, 2012).

To meet the demand of pulse, pigeonpea productivity has to be increased. Effective management of irrigation water is an important issue in crop production, since irrigation is a precondition for crop growth, development and production per mm of water and productivity per unit area. Hence, the present study was initiated to study the influence of drip irrigation and mulch on yield and water use efficiency in rabi pigeon pea.

\section{Materials and Methods}

The experiment was conducted during the rabi season in 2017-18 at College Farm, CAET, NAU, Dediapada, to study the "Response of pigeon pea to drip irrigation and mulching". The research where the present experiment was conducted is situated at $21^{\circ} 37^{\prime} 38.6^{\prime \prime} \mathrm{N}$ latitude, $73^{\circ} 34^{\prime} 58.5^{\prime \prime} \mathrm{E}$ longitude and an altitude with an elevation of $169 \mathrm{~m}$ above mean sea level. The soil of experimental plot was clayey loam in texture and slightly alkaline in reaction $(\mathrm{pH} 7.82)$, normal electrical conductivity $(0.32 \mathrm{dS} / \mathrm{m})$ and low availability organic carbon (0.34) with soil was low available nitrogen (204.32 $\mathrm{kg} / \mathrm{ha}$ ), medium available phosphorus (31.48 $\mathrm{kg} / \mathrm{ha}$ ) and low available potassium (66.55 $\mathrm{kg} / \mathrm{ha}$ ). The treatment combinations were laid out in randomized block design with four replications. The experiment consists five treatments were as follows: $\mathrm{T}_{1}$ - Drip irrigation with 0.6 PEF, $\mathrm{T}_{2}$ - Drip irrigation with 0.6 PEF, Drip + Black Plastic Mulch $50 \mu$ with (56\% coverage), $\mathrm{T}_{3}$ - Drip irrigation with 0.6 PEF, Drip + sugarcane trash mulch @ 5 t/ha with (56\% coverage), $\mathrm{T}_{4}$ - surface irrigation IW/CPE: 1, $60 \mathrm{~mm}$ depth + sugarcane trash mulch @ 5 t/ha (56\% coverage) and $\mathrm{T}_{5}$ surface irrigation IW/CPE: 1 (control) with 60 $\mathrm{mm}$ depth. Irrigations were scheduled based on the USWB Class A pan evaporation rates for treatments under drip irrigation and surface (control) irrigation, the calculated irrigation water was delivered in treatment plot directly measuring water flow. Recommended doses of fertilizer, i.e. 20:40:0 $\mathrm{kg}$ NPK ha ${ }^{-1}$ was applied through urea and single super phosphate at time of sowing. Pigeon pea crop was sown in $21^{\text {st }}$ of November at a spacing of $60 \times 20: 120 \mathrm{~cm}$ in paired row experimentation and harvested at the physiological maturity stage in the end of April. Pigeon pea variety GT-102 was used as test variety, before sowing seeds were treated with dithane M-45 fungicide, imida 35FS 
insecticide and Rhizobium culture. The treated seeds sown by dibbling, two to three seeds up to 3 to $4 \mathrm{~cm}$ depth in the row following spacing as per the treatments after wards only one plant per hill was maintained. The growth and yield observations were recorded in ten plants randomly selected in each treatment.

\section{Results and Discussion}

\section{Interaction effect of mulching and irrigation}

Among the different mulch treatments, mulching with black plastic mulch of $50 \mu$ and organic mulch (sugarcane trash @ $5 \mathrm{t} / \mathrm{h}$ ) appreciably increased plant height and number of secondary branches of pigeonpea might be due to mulching lead to better plant growth by changing the micro climate through conserving moisture by virtue of reducing evaporation, modifying soil moisture and soil temperature, controlling weeds, thus economizing the use of irrigation water to crop. Moreover, adequate availability of moisture to plant, results in full cell turgidity and eventually higher meristematic activity, leading to more foliage development, greater photosynthetic rate and consequently better plant growth. These results are in conformity with findings of Yadav et al., (2006) and Mahalakshmi et al., (2011). The plant height was increased progressively up to the harvest with the advancement of crop growth stages. Increase in average plant height of pigeon pea was rather slow up to $30 \mathrm{DAS}$, there after it increased linearly up to 120 DAS, and after that although it continued to increase until maturity it occurred at diminishing rate in different irrigation treatments. Almost similar trend was observed by Ghosh and Biswas (1984) and Mahalakshmi et al., (2011). The plant height was measured at 30, 60, 90, 120 DAS and at harvest, growth and vegetative period significantly higher plant height observed in treatment $T_{2}$, after that lead to reproductive stage in significantly higher plant observed in organic mulch, show in (Table 1) and graphically illustrated in Figure 1. Number of secondary branches during the initial crop growing period, i.e., up to 30 and 60 DAS, there was not any significant effect on the number of secondary branches per plant. There after recorded at 90, 120 DAS and at harvest were 90 DAS significantly higher secondary branches in treatment $T_{2}$ after that lead to 120 DAS and at harvest significantly higher secondary branches in organic mulch treatment, show in (Table 1) and graphically illustrated in Figure 2.

The interaction effect observed between irrigation and mulch were significant in respect to plant height, yield attributes and yields of pigeon pea. The plant height and number of secondary branches were significantly higher in mulch treatment with respect to over rest treatments. While number of pods and grain weight per plant also significantly highest under 0.6 PEF with organic mulch $\left(\mathrm{T}_{3}\right)$. Data show in (Table 2), remarkably the higher grain yield registered of $3318.49 \mathrm{~kg} / \mathrm{ha}$ than the treatment $\mathrm{T}_{4}$ with $2771.36 \mathrm{~kg} / \mathrm{ha}$ and at par with treatment $\mathrm{T}_{1}$ registered $2718.92 \mathrm{~kg} / \mathrm{ha}$. Mulch treatment $\mathrm{T}_{3}$ recorded significantly higher haulm yield of $2615.24 \mathrm{~kg} / \mathrm{ha}$ registered than treatment $\mathrm{T}_{4}$ registered $2333.41 \mathrm{~kg} / \mathrm{ha}$ and at par with treatments $T_{1}$ and $T_{2}$ registered of 2329.08 and $2267.72 \mathrm{~kg} / \mathrm{ha}$ respectively. Here also mulch treatment $T_{3}$ recorded significantly higher fodder yield registered $2712.21 \mathrm{~kg} / \mathrm{ha}$ and at par with treatments $\mathrm{T}_{2}, \mathrm{~T}_{4}$ and $\mathrm{T}_{1}$ registered of 2598.26, 2519.89 and 2391.18 $\mathrm{kg} / \mathrm{ha}$ respectively. Among mulch treatment $\mathrm{T}_{3}$ recorded significantly higher stalk yield registered $7749.17 \mathrm{~kg} / \mathrm{ha}$ and which were at par with treatments $\mathrm{T}_{2}, \mathrm{~T}_{4}$ and $\mathrm{T}_{1}$ registered $7423.61, \quad 7199.69$ and $6831.94 \mathrm{~kg} / \mathrm{ha}$ respectively. These results were in conformity with findings of Duraisamy and 
Manickasundaram (2008). Treatment $\mathrm{T}_{3}$ recorded significantly higher dry root weight registered $1590.28 \mathrm{~kg} / \mathrm{ha}$ and at par with treatment $\mathrm{T}_{4}$ registered $1437.50 \mathrm{~kg} / \mathrm{ha}$ which also at par with treatments $T_{2}$ and $T_{1}$ registered of 1364.67 and $1335.13 \mathrm{~kg} / \mathrm{ha}$ respectively. Frequent application of water through drip irrigation and mulching with lower moisture replenishing rates seemed that resulted in higher root characters with more adventitious roots due to higher availability of moisture this result higher dry root weight. The surface irrigation with conventional method resulted in lower root zone moisture content and root dry weight (Brandt et al., 1971; Lemon and Erickson, 1955). The water use efficiency and water saving obtained under irrigation levels of $0.6 \mathrm{PEF}$ and IW/CPE:1 through drip and surface irrigation respectively. This indicated that WUE decreased with increase in level of irrigation (Table 3). The treatment $\mathrm{T}_{3}$ recorded significantly highest harvest index registered
$24.26 \%$ and at par with treatments $\mathrm{T}_{1}$ and $\mathrm{T}_{4}$ registered of 22.89 and $22.57 \%$ respectively. These results are accordance with those of Ramachandrappa et al., (1992) and Sandhu et al., (1992).

\section{Effect of irrigation and mulching on soil physico-chemical properties of pigeonpea}

Soil $\mathrm{pH}$, electrical conductivity and organic carbon were slight influenced by irrigation and mulching during the experimental year. Available nitrogen, phosphorus and potassium were not influenced by the irrigation and mulching, however there were slight increase in nitrogen and of phosphorus and potassium up take at harvest, show in (Table 4). Similar result findings were obtained by Swathi et al., (2017) who also found no significant change in soil fertility status due to irrigation and mulching.

Table.1 Plant height and number of secondary branches per plant at different stages

\begin{tabular}{|c|c|c|c|c|c|c|c|c|}
\hline \multirow{2}{*}{ Treatments } & \multicolumn{4}{|c|}{ Plant height (cm) at different stages } & \multicolumn{3}{c|}{$\begin{array}{c}\text { Number of secondary } \\
\text { branches per plant }\end{array}$} \\
\cline { 2 - 9 } & 30 DAS & 60 DAS & 90 DAS & 120 DAS & At harvest & 90 DAS & 120 DAS & At harvest \\
\hline $\mathbf{T}_{\mathbf{1}}$ & 16.88 & 53.24 & 102.83 & 163.73 & 175.13 & 8.77 & 15.32 & 20.57 \\
\hline $\mathbf{T}_{\mathbf{2}}$ & 23.38 & 75.20 & 126.83 & 168.65 & 176.15 & 12.90 & 14.36 & 20.11 \\
\hline $\mathbf{T}_{\mathbf{3}}$ & 19.65 & 59.74 & 116.00 & 174.53 & 182.66 & 9.53 & 17.54 & 23.04 \\
\hline $\mathbf{T}_{\mathbf{4}}$ & 18.72 & 55.58 & 110.63 & 165.98 & 178.14 & 8.98 & 15.28 & 21.12 \\
\hline $\mathbf{T}_{\mathbf{5}}$ & 16.05 & 45.72 & 99.36 & 152.95 & 169.15 & 6.35 & 14.05 & 18.30 \\
\hline $\mathbf{M e a n}^{*}$ & 18.93 & 57.89 & 111.13 & 165.17 & 176.24 & 9.30 & 15.31 & 20.63 \\
\hline S.Em. $\mathbf{\pm}$ & 0.31 & 3.54 & 5.10 & 4.29 & 2.55 & 0.69 & 0.70 & 0.89 \\
\hline CD 5 \% & 0.96 & 10.91 & 15.70 & 13.23 & 7.85 & 2.12 & 2.15 & 2.74 \\
\hline C.V. \% & 3.28 & 12.23 & 9.17 & 5.20 & 2.89 & 14.80 & 9.10 & 8.62 \\
\hline
\end{tabular}


Table.2 Yields and water use efficiency of rabi pigeon pea as influenced by different levels of irrigation and mulch

\begin{tabular}{|c|c|c|c|c|c|c|c|c|c|}
\hline Treatments & $\begin{array}{l}\text { Grain } \\
\text { yield } \\
\text { (kg/ha) }\end{array}$ & $\begin{array}{c}\text { Haulm } \\
\text { yield } \\
\text { (kg/ha) }\end{array}$ & $\begin{array}{c}\text { Fodder } \\
\text { yield } \\
\text { (kg/ha) }\end{array}$ & $\begin{array}{c}\text { Stalk } \\
\text { yield } \\
\text { (kg/ha) }\end{array}$ & $\begin{array}{c}\text { Dry root } \\
\text { weight } \\
\text { (kg/ha) }\end{array}$ & $\begin{array}{l}\text { Harvest } \\
\text { index } \\
(\%)\end{array}$ & $\begin{array}{c}\text { Water use } \\
\text { efficiency } \\
(\mathrm{kg} / \mathrm{ha}- \\
\mathrm{mm})\end{array}$ & $\begin{array}{c}\text { Water } \\
\text { saving over } \\
\text { surface } \\
\text { irrigation of } \\
\mathbf{T}_{4}(\%)\end{array}$ & $\begin{array}{c}\text { Water } \\
\text { saving over } \\
\text { surface } \\
\text { irrigation of } \\
\mathbf{T}_{5}(\%)\end{array}$ \\
\hline $\mathbf{T}_{1}$ & 2718.9 & 2329.08 & 2391.18 & 6831.94 & 1335.13 & 22.89 & 5.6 & 34.79 & 28.11 \\
\hline $\mathbf{T}_{2}$ & 2353.3 & 2267.72 & 2598.26 & 7423.61 & 1364.67 & 19.61 & 4.85 & 34.79 & 28.11 \\
\hline$T_{3}$ & 3318.5 & 2615.24 & 2712.21 & 7749.17 & 1590.28 & 24.26 & 6.84 & 34.79 & 28.11 \\
\hline $\mathbf{T}_{4}$ & 2771.4 & 2333.41 & 2519.89 & 7199.69 & 1437.50 & 22.57 & 3.72 & - & - \\
\hline $\mathbf{T}_{5}$ & 1836.9 & 1978.15 & 1867.64 & 5336.11 & 1247.92 & 20.06 & 2.72 & 9.3 & - \\
\hline mean & 2599.8 & 2304.72 & 2417.84 & 6908.11 & 1395.1 & 21.88 & 4.75 & - & - \\
\hline S.Em. \pm & 108.17 & 75.82 & 111.86 & 319.61 & 51.71 & 0.88 & 0.21 & - & - \\
\hline CD $5 \%$ & 333.29 & 233.62 & 344.69 & 984.82 & 159.34 & 2.72 & 0.64 & - & - \\
\hline C.V. $\%$ & 8.32 & 6.58 & 9.25 & 9.25 & 7.41 & 8.06 & 8.72 & - & - \\
\hline
\end{tabular}

Table.3 Economics of rabi pigeon pea as influenced by different levels of irrigation and mulch

\begin{tabular}{|c|c|c|c|c|}
\hline Treatments & $\begin{array}{c}\text { Gross income } \\
\text { (Rs/ha) }\end{array}$ & $\begin{array}{c}\text { Total production } \\
\text { cost }(\mathbf{R s} / \mathbf{h a})\end{array}$ & $\begin{array}{c}\text { Net return } \\
\text { (Rs/ha) }\end{array}$ & $\begin{array}{c}\text { Benefit cost } \\
\text { ration }\end{array}$ \\
\hline $\mathbf{T}_{\mathbf{1}}$ & 142856 & 38560 & 104295.64 & 2.70 \\
\hline $\mathbf{T}_{\mathbf{2}}$ & 124776 & 40070 & 84705.90 & 2.11 \\
\hline $\mathbf{T}_{\mathbf{3}}$ & 173722 & 37246 & 136475.99 & 3.66 \\
\hline $\mathbf{T}_{\mathbf{4}}$ & 145668 & 34998 & 110669.91 & 3.16 \\
\hline $\mathbf{T}_{\mathbf{5}}$ & 59229 & 34410 & 24819.02 & 0.72 \\
\hline
\end{tabular}

Table.4 Effect of irrigation and mulching on soil physico-chemical properties of pigeonpea

\begin{tabular}{|c|c|c|}
\hline Parameter & Before sowing & After harvest \\
\hline $\mathbf{p H}$ & 7.82 & 7.81 \\
\hline $\mathbf{E C}\left(\mathbf{d S m}^{-\mathbf{1}}\right)$ & 0.32 & 0.43 \\
\hline $\mathbf{O C} \%$ & 0.34 & 0.40 \\
\hline $\mathbf{N}(\mathbf{k g} / \mathbf{h a})$ & 204.32 & 240.42 \\
\hline $\mathbf{P}_{\mathbf{2}} \mathbf{O}_{\mathbf{5}}(\mathbf{k g} / \mathbf{h a})$ & 31.48 & 22.52 \\
\hline $\mathbf{K}_{\mathbf{2}} \mathbf{O}(\mathbf{k g} / \mathbf{h a})$ & 66.55 & 41.76 \\
\hline
\end{tabular}


Fig.1 Effect of irrigation and mulching on plant height at different stages of pigeonpea

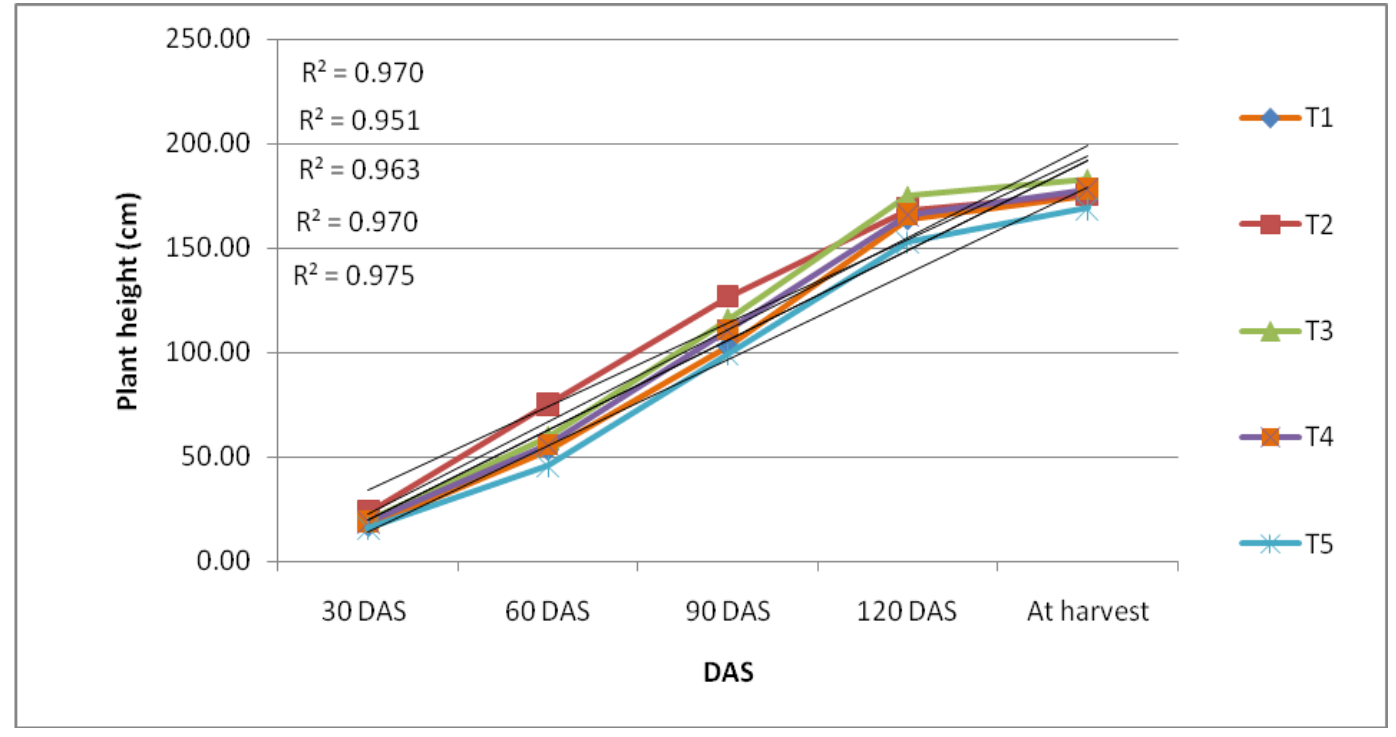

Fig.2 Effect of irrigation and mulching on number of secondary branches per plant of pigeonpea at different growth stages

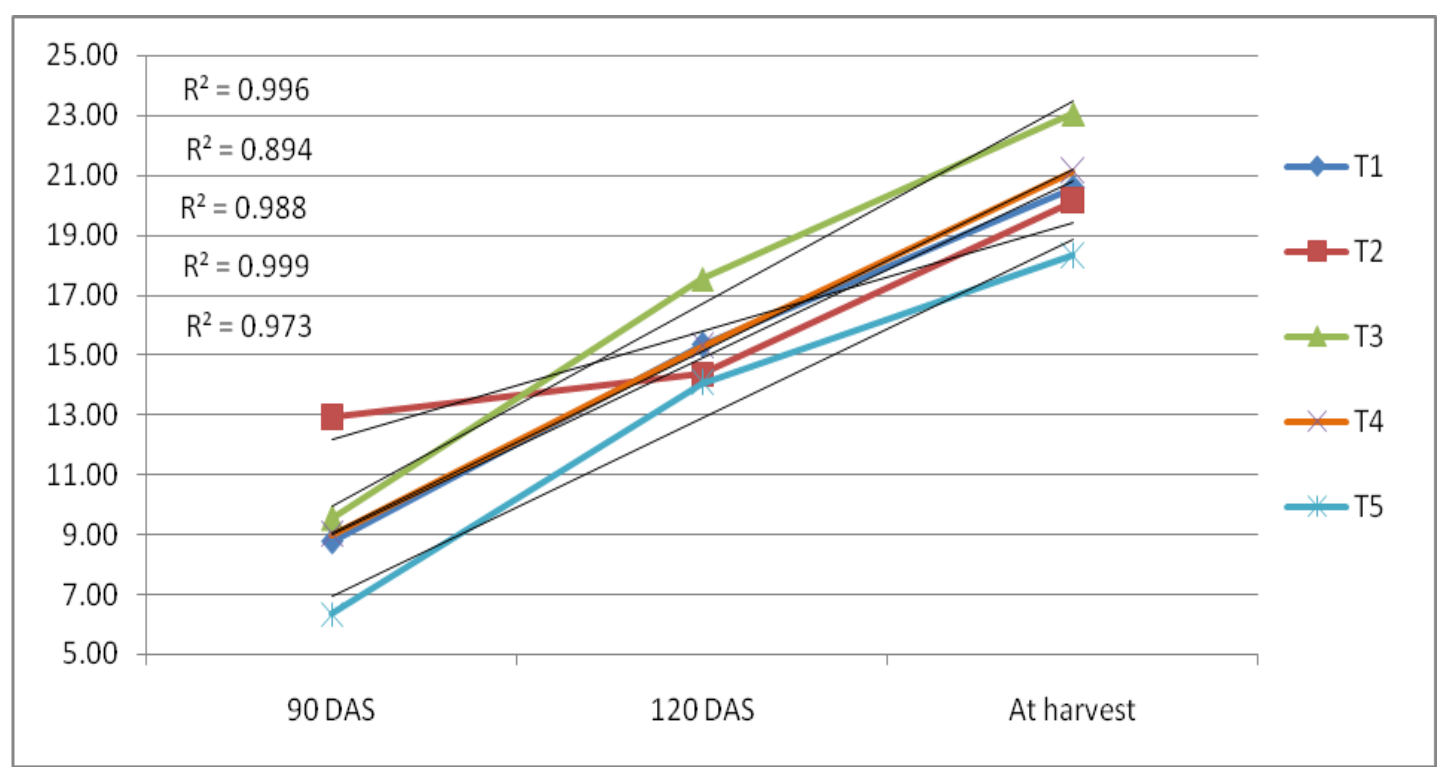

In conclusion, based on result it is recommended that pigeonpea (CV. GT-102) can be grown during rabi season under Dediapada Taluka region conditions irrigated with drip irrigation (discharge 4 lph) 0.6 PEF + sugarcane trash mulch @ 5 t/ha, throughout the crop life with an optimal seasonal water requirement of $485.14 \mathrm{~mm}$, which was given maximum yield of $3318.49 \mathrm{~kg} / \mathrm{ha}$ with net realization of Rs 136475.99/ha. It is also observed that the second highest yield was found in surface irrigation (IW/CPE: 1, 60 mm depth + sugarcane trash mulch @ 5 t/ha) with $2771.36 \mathrm{~kg} / \mathrm{ha}$ yield and 110669.91 $\mathrm{Rs} /$ ha net income over rest of the treatments. 


\section{References}

Anonymous (2010) Directorate of economics and statistics, department of agriculture and cooperation. (GSWAN).

Brandt A, Bresler E, Diner N, Ben-Asher I, Heller J, Goldberg D. (1971). Infiltration from a Trickle Source: Proceedings of Soil Science Society of America, 35(5): 675 -82.

Domoguen, R. L., Saxena, K. B., Mula, M. G., Sugui, F and Dar, W. D. (2010). The multiple uses of pigeonpea. Available at http:// ww.sunstar.com.ph /baguio/ multiple-uses -pigeonpea.

Duraisamy, V. K. and Manickasundaram, P. (2008). Agronomic management for perennial redgram through irrigation and mulching. Madras Agricultural Journal, 95(1-6): 205 - 207.

Ghosh, D. C. and Biswas, S. K. (1984). Influence of irrigation and straw mulch on growth and yield of sesamum grown in summer season. Indian Agriculturist, 28(4): 275 - 279.

Lemon, E. R. and Erickson, A. E. (1955). Principle of the platinum microelectrode as a method of characterizing soil aeration. Soil Science, 79(5): 383 392.

Mahalakshmi, K., Kumar, K. A., Reddy, M. D. and Devi, M. U. (2011e4). Response of rabi pigeonpea [Cajanus cajan (L.)] to different levels of drip irrigation. Journal of Research, 39(4): 101 - 103.

NNMB (2012). Diet and nutritional status of rural population, prevalence of hypertension and diabetes among adults and infant and young child feeding practices. National Nutrition Monitoring Bureau Technical Report No. (26): 11.
Ramachandrappa, B. K., Kulkarni, K. R. and Nanjappa, H. V. (1992). Stress-day index for scheduling irrigation in summer groundnut (Arachis hypogaea). Indian Journal of Agronomy, 37(2): 276 - 279.

Sandhu, B. S., Khera, K. L. and Ranjan, M. S. (1992). Response of summer mung bean to irrigation and straw mulching on a loamy sand soil in northern India. Journal of the Indian Society of Soil Science, 40(2): 240 - 245.

Swathi, Y., M., Srinivasa M., R., Prabhakara G., R., and Kavitha P. (2017) Influence of density, planting patterns and mulching on yield of- drip irrigated pigeonpea [Cajanus cajan (L.) Millsp]. Indian Journal of Agricultural Research. 51(6): 611-614.

Vanaja, M., Ram Reddy, P. R., Lakshmi, N. J., Abdul Razak, S. K., Vagheera, P., Archana, G., Yadav, S. K., Maheswari, M. and Venkateswarlu, B. (2010). Response of seed yield and its components of red gram (Cajanus cajan L. Millsp.) to elevated $\mathrm{CO}_{2}$. Plant, Soil and Environment, 56: 458 - 462.

Wu, N., Fu, K., Fu, Y. J., Zu, Y.G., Chang, F. R., Chen, Y.H., Liu, X. L., Kong, Y., Liu, W. and Gu, C.B. (2009). Antioxidant activities of extracts and main components of pigeonpea [Cajanus cajan (L.) Millsp.] leaves. Molecules, 14: 1032 - 1043.

Yadav, R. D., Pareek, R. G. and Yadav, R. L. (2006). Effect of mulching and sulphur on growth and yield of mustard under varying levels of irrigation. Journal of Oilseeds Research, 23(2): 219-21.

\section{How to cite this article:}

Solanki, M.A., A.L. Chalodia, M.H. Fadadu and Dabhi, P.V. 2019. Response of Pigeon Pea to Drip Irrigation and Mulching. Int.J.Curr.Microbiol.App.Sci. 8(02): 91-97. doi: https://doi.org/10.20546/ijcmas.2019.802.011 